\title{
GOMER - ANTYIDEAŁ ŻONY CZY WZORCOWA METAFORA RELACJI OBLUBIEŃCZEJ NA PODSTAWIE HIERONIMOWEGO KOMENTARZA DO OZ 1-3?
}

Vade, sume tibi uxorem fornicationum $(\mathrm{Oz} 1,2)$

Ta najstarsza wypowiedź w tekstach prorockich o zawarciu małżeństwa rozpoczyna się od imperatywu Boga skierowanego do proroka Ozeasza, aby wziął za żonę kobietę cudzołożną. W owym poleceniu zaskakujący jest fakt, że Bóg nakazuje Izraelicie poślubienie prostytutki ${ }^{1}$. Z kolei w $\mathrm{Oz} \mathrm{3,1}$ jest mowa o „pokochaniu tej, która kocha innego"². Historia powołania Ozeasza i jego małżeństwo z prostytutką Gomer, zapisane na kartach Oz 1-3 doczekało się bardzo wielu interpretacji ${ }^{3}$.

* Dr Magdalena Jóźwiak - wykładowca na Papieskim Wydziale Teologicznym we Wrocławiu oraz w Instytucie Studiów Klasycznych, Śródziemnomorskich i Orientalnych Uniwersytetu Wrocławskiego; lektor w Szkole Języków Antycznych i Orientalnych przy Wydziale Filologicznym Uniwersytetu Wrocławskiego; e-mail: mjozwiak.uni.wr@gmail.com.

${ }^{1}$ Autorzy biblijni zawsze wobec takich kobiet wypowiadali się negatywnie, a kobiety zajmujące się tą profesją skazywano na śmierć, jak na przykład Tamar (por. Rdz 38, 24).

${ }^{2}$ Ów problem relacji chronologicznej pomiędzy pierwszym rozkazem o „wzięciu za żonę kobiety cudzołożnej” $(\mathrm{Oz}$ 1, 2), a drugim - o ,pokochaniu tej, która kocha innego” $(\mathrm{Oz} 3,1)$, stał się przedmiotem badań wielu egzegetów. Dla przykładu M.A. Sweeney (The Twelve Prophets, vol. 1: Hosea, Joel, Amos, Obadiah, Jonah, Collegeville 2000, 38-39) sugeruje, że chodzi o dwie różne kobiety. Z kolei H.W. Wolff (A Commentary on the Book of the Prophet Hosea, Minneapolis 1974, 59) mówi o treściowej tożsamości dwóch narracji. Oz 3 opowiadałby to samo wydarzenie co Oz 1. W przekonaniu Wolffa różnice w narracjach wynikają z różnego ich autorstwa. Inni egzegeci bronią ciągłości narracyjnej wewnątrz Oz 1-3. Rozdział 1. opisywałby początki małżeństwa, rozdział 3. zaś wskazywałby na moment ponownego przyjęcia przez proroka niewiernej żony, por. F.I. Andersen - D.N. Freedman, Hosea: A New Translation with Introduction and Commentary, New York 1980, 292-294).

${ }^{3}$ Rozmaite propozycje na temat interpretacji Oz 1-3 zostały zebrane w publikacji: B. Kelle, Hosea 1-3 in Twentieth-Century Scholarship, „Currents in Biblical Research” 7 (2009) 179-216. Tam też zamieszczono obszerną bibliografię traktującą o tej kwestii (s. 210-216). Z publikacji w języku polskim warto odnotować: W. Pikor, ,, «Albowiem Bogiem jestem, nie człowiekiem» (Oz 11, 9). Miłosierdzie jako objawienie 'inności'Boga w świetle proroctwa Ozeasza”, w: „,Dobrze, stugo dobry...” (Mt 25, 21). Ksiega Pamiqtkowa ku czci Ks. Dr Huberta Ordona SDS, red. K. Mielcarek, Studia Biblica 9, Kielce 2005, 105-125; E. Sujecka, Symbolika matzeństwa w Księdze Ozeasza, w: Studia z biblistyki, t. 7, red. R. Bartnicki, Warszawa 1994, 241-315. 
W niniejszym artykule chcielibyśmy przedłożyć Hieronimowe stanowisko na temat prostytutki Gomer - żony proroka Ozeasza. Temat zaprezentujemy w dwóch odsłonach. Po pierwsze omówimy zagadnienie ideału kobiety w rozumieniu św. Hieronima. A następnie przedstawimy obraz Gomer w Hieronimowym komentarzu do Oz 1-3. Spróbujemy udzielić odpowiedzi na pytanie, jak Książę Egzegetów radzi sobie z przekazem biblijnym, według którego Gomer nie dość, że jest mężatką (a wiadomo, że Hieronim niezbyt przychylnie odnosił się do tego stanu), to jeszcze jest prostytutką!

1. Ideal kobiety w rozumieniu św. Hieronima. W opinii Hieronima dziewictwo jest najdoskonalszym stanem życia kobiet chrześcijańskich. Temu zagadnieniu autor Wulgaty poświęcił bardzo dużo miejsca w swej twórczości, a szczególnie w Listach. Warto wspomnieć choćby List $22^{4}$ do Eustochium, córki Pauli, o strzeżeniu dziewictwa. Ten obszerny traktat poświęcony dziewictwu, choć jest adresowany do Eustochium, to z pewnością był pisany z myślą o szerszym gronie odbiorców ${ }^{5}$. Hieronim swoją argumentację na temat dziewictwa jako najdoskonalszego stanu oparł oczywiście na Piśmie Świętym ${ }^{6}$. Pomimo tego, iż mnich z Betlejem był żarliwym apologetą i piewcą życia $\mathrm{w}$ dziewictwie, to jednak ten stan był dla wielu kobiet nieosiagalny. Zresztą „rzymskie arystokratki”, których duchowym przewodnikiem był Hieronim w dużej mierze należały do stanu wdowiego. Stąd autor Wulgaty w swych Listach, kieruje także wiele wskazówek do wdów, powołując się na biblijne wzory życia wdowiego ${ }^{7}$. W swej epistolarnej spuściźnie nie pominął oczywiście mężatek i nauczania Pisma Świętego o małżeństwie, choć ten stan był najniżej przez niego ceniony, co nie musi od razu oznaczać, że nim pogardzał ${ }^{8}$. A zatem, skoro Hieronim kierował swe listy do dziewic, wdów (którym był winny wdzięczność za wsparcie finansowe) oraz do mężatek, to pośród którego z tych stanów znajduje się najwięcej idealnych kobiet? Odpowiedź nie jest tak oczywista, jakby się mogło wydawać, ponieważ w opinii świętego ze Strydonu idealną kobietą jest ta, która zachowuje cnotę czystości.

${ }^{4}$ Por. inne istotne listy Hieronimowe podejmujące tę tematykę: List 130 do Demetriady; List 107 do Lety; List 128, adresowany do Gaudencjusza; List 45 do Aseli; List 108 „Epitafium matki Pauli” oraz List 117, adresowany do „matki i córki mieszkających w Galii”. Oprócz Listów warto zwrócić jeszcze uwagę na dwa polemiczne dzieła, traktujące o tematyce dziewictwa. Pierwszym $\mathrm{z}$ nich jest Adversus Helvidium de perpetua virginitate beatae Mariae - dzieło powstało w 383 roku. Tutaj Hieronim zwraca się przeciw opinii, że Maryja i Józef mieli dzieci po narodzeniu Jezusa. Drugie dzieło, to Adversus Iovianum, w którym Hieronim broni swego ascetycznego ideału przed Jowianem, który nauczał, że dziewictwo nie przewyższa małżeństwa, że ochrzczony nie może upaść, że post jest bezwartościowy i że nagroda w niebie jest dla wszystkich jednakowa.

${ }^{5}$ Por. J.N.D. Kelly, Hieronim. Życie, pisma, spory, tłum. R. Wiśniewski, Warszawa 2003, 119-120.

${ }^{6}$ Szerzej na ten temat: T. Radliński, Św. Hieronim a kobiety, Lublin 2013, 116-122.

${ }^{7}$ Por. tamże, s. 146-152.

${ }^{8} \mathrm{Na}$ temat stosunku Hieronima do instytucji małżeństwa zob. tamże, s. 173-189. 
W przekonaniu Hieronima owo życie w czystości będzie się wiązało raczej ze stylem życia, niż ze stanem. Czyli w jego rozumieniu życie cnotą czystości nie oznacza od razu dziewictwa w dosłownym rozumieniu tego słowa, będzie to raczej forma aktywności w przeżywaniu płci, szukanie woli Bożej w swym życiu oraz wcielanie w życie miłości nie skażonej grzechem pożądania9. Hieronim odnosi cnotę czystości zarówno do dziewic, małżonek i wdów, pisząc raz o czystości ciała i duszy kobiet poświęconych Bogu, innym razem o czystych i nieskalanych łożach, a jeszcze innym o świętych wdowach ${ }^{10}$. Ideał kobiety dla Hieronima to kobieta żyjąca w cnocie czystości: duchem i ciałem. Mnich z Betlejem owe ideały kobiet nazywa oblubienicami i małżonkami. Ta kompilacja wynika z jego teorii, że dziewictwo cielesne nie zawsze idzie $\mathrm{w}$ parze $\mathrm{z}$ dziewictwem duchowym ${ }^{11}$. Wspominając o dziewicach mówi, że wśród nich są takie, które nie z własnego wyboru, ale przez rodziców, już od samego poczęcia zostały przeznaczone na służbę Chrystusowi ${ }^{12}$. Ów Ojciec Kościoła podkreśla, że każda kobieta jest oblubienicą Pana bez względu na to, w jakim stanie żyje. I choć zaznacza, iż dziewice są pierwsze w dawaniu świadectwa o ich przynależności przez cnotę czystości do Oblubieńca, to jednak kobieta poślubiona mężowi też może o tym świadczyć13.

Reasumując, ideałem kobiety w opinii Hieronima może być dziewica, wdowa lub małżonka, o ile odznacza się cnotą czystości w połączeniu z predyspozycjami do pracy umysłowej, dokonującej się poprzez systematyczne czytanie i zgłębianie Pisma Świętego z zachowywaniem ascezy oraz pełnieniem dzieł miłosierdzia.

2. Obraz Gomer w Hieronimowym komentarzu do Oz 1-3. Książę Egzegetów, szczycący się znajomością języka hebrajskiego w swoich pismach egzegetycznych wyprowadza etymologię prawie każdej nazwy własnej, która występuje w komentowanym przez niego tekście. Stąd, prezentując stanowisko Hieronima na temat problematycznej żony Ozeasza, chcielibyśmy na początku przywołać Hieronimowe rozważania o znaczeniu imienia Gomer. Komentując Oz 1, 3-4 podaje wachlarz możliwości interpretacji tego imienia. Odnotowuje

${ }^{9}$ Por. Hieronymus, Epistula 22, 23, ŹMT 54 [tekst łacińsko-polski, tekst łac. i oprac. H. Pietras, tłum. J. Czuj, oprac. M. Ożóg], Kraków 2010, 97: „Ja postępuję inną drogą; dziewictwa nie wysławiam tylko, lecz je także zachowuję. I nie wystarczy wiedzieć, co jest dobre, jeśli się nie strzeże pilnie tego, co się obrało; bo wiedza dotyczy sądu, a urzeczywistnienie jest dziełem pracy. Pierwsze jest dostępne dla wielu, drugie tylko dla nielicznych. [...] Minął już cień, teraz jest sama prawda. Ty wprawdzie z prostotą mówisz i łagodna nie patrzysz z góry nawet na nieznajomych, ale oczy bezwstydne inaczej widzą. Nie umieją patrzeć na piękność duszy, lecz ciała”.

${ }^{10}$ Por. np. tenże, Epistula 22, 2, ŹMT 54, 83; tamże 54, 1, ŹMT 55, 37.

${ }^{11}$ Tamże 22, 5, ŹMT 54, 85: „Panieństwo traci się więc i myślą. Oto panny złe, które dziewictwo zachowują tylko na ciele, a nie na duszy; oto panny głupie, które nie mając oleju odłączone są od oblubieńca (por. Mt 25, 1-12)".

${ }^{12}$ Por. np. tamże 107, 3, ŹMT 61, 150-151.

${ }^{13}$ Por. np. tamże 49, 15, ŹMT 54, 212-213. 
mianowicie, że Gomer przede wszystkim znaczy „doskonała” (consummata) oraz „ukończona” (perfecta) $)^{14}$, czyli taka, której już nic nie brakuje ${ }^{15}$. Następnie Hieronim podaje, że inni to imię interpretuja jako „pancerz” (lorica) ${ }^{16}$.

Autor Wulgaty odnotowuje także, że są tacy, którzy imię Gomer odczytuja jako „miara” (mensura) ${ }^{17}$. I tu znowu trzeba się odnieść do „świętego języka”. Ta interpretacja jest błędna, ponieważ „miara” po hebrajsku to tej interpretacji pomylił więc wygłosową spółgłoskę RESZ (ר) z DALET ( ( ), które są $\mathrm{W}$ zapisie bardzo do siebie podobne. Trzeba też pamiętać, że pierwotnie hebrajski tekst Biblii był zapisany w formie spółgłoskowej i taką wersją dysponował Hieronim, stąd nietrudno o pomyłkę. Na końcu tego passusu Hieronim zaznacza, że „są i tacy, którzy podejrzewają" iż Gomer znaczy „gorycz” (amaritudo). Odnosząc się krytycznie do tego wyjaśnienia, autor Wulgaty jako znawca języka hebrajskiego poucza, że ta interpretacja byłaby słuszna, gdyby imię Gomer nie składało się z trzech spółgłosek: GIMEL (^)-MEM (घ)RESZ ( ()$^{19}$. Mianowicie zwolennicy tej etymologii wyrzucili z trójspółgłoskowego imienia pierwszą spółgłoskę, czyli GIMEL, zostało im MEM oraz RESZ, a po hebrajsku ,gorycz" to רئ ${ }^{20}$, czyli słowo składające się ze spółgłosek MEM i RESZ. Trudno usprawiedliwić taką pomyłkę, gdyż wskazuje ona na słabą znajomość alfabetu, co jest oczywiście podstawową umiejętnością w nauce każdego języka.

Wyprowadzając etymologię imienia męża Gomer, Hieronim podaje wyłącznie jedną interpretację. Otóż imię Ozeasz tłumaczy jako „zbawiciel”, gdyż na początku komentarza odnotowuje:

${ }^{14}$ Przedkładając taką etymologię, Hieronim bazuje oczywiście na języku hebrajskim i wyprowadza to imię od czasownika גֶ, - „być uzupełnionym”, „być całym”, „kończyć się”. Por. L. Koehler - W. Baumgartner - J.J Stamm, Wielki stownik hebrajsko-polski i aramejsko-polski Starego Testamentu, red. wyd. pol. P. Dec, t. 1, Warszawa 2008, 187, nr 1783.

15 Por. Hieronymus, Commentaria in Osee 1, 3-4, PL 25, 824D: „Gomer interpretatur $\tau \varepsilon \tau \varepsilon \lambda \varepsilon \sigma \mu \varepsilon \dot{v} \eta$, id est, «consummata», atque «perfecta»".

${ }^{16}$ Por. tamże: „alii $\theta \omega ́ \rho \alpha \kappa \alpha \varsigma$, id est, «loricas», significari putant”. Wyprowadzając etymologię

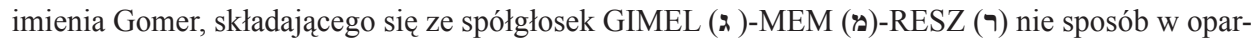
ciu o język hebrajski wyjaśnić, dlaczego niektórzy to imię rozumieją jako gr. $\theta \omega ́ \rho \alpha \xi$, a łac. lorica. Słownik języka hebrajskiego nie zawiera słowa, które na bazie tych trzech spółgłosek znaczyłoby „pancerz”. W słowniku hebrajsko-łacińskim słowo lorica jest tłumaczone przede wszystkim jako שִּריוּ (por. Lexicon Hebraicum et Chaldaicum in Libros Veteris Testamenti ordine etymologico compositum, ed. E.F. Leopold, Lipsiae 1850, 421). W tym miejscu nie mamy do czynienia z błędem tekstologicznym. Autor Wulgaty nie odczytuje źle liter hebrajskich, ani ich nie pomylił, lecz wydaje się, że bez weryfikacji przepisuje tę informację ze źródła, którym dysponuje.

${ }^{17}$ Por. Hieronymus, Commentaria in Osee 1, 3-4, PL 25, 824D: ,Sunt qui «mensuram» [...] suspicentur".

${ }^{18}$ Por. Koehler - Baumgartner - Stamm, Wielki słownik hebrajsko-polski, t. 1, s. 186, nr 1772.

${ }^{19}$ Por. Hieronymus, Commentaria in Osee 1, 3-4, PL 25, 824D: „Sunt qui [...] «amaritudinem» suspicentur, qui [Al. quod] recte dicerent, si GIMEL litteram non haberet".

${ }^{20}$ Por. Koehler - Baumgartner - Stamm, Wielki stownik hebrajsko-polski, t. 1, s. 592, nr 5492. 
„«Ozeasz» bowiem w naszym języku znaczy «zbawiciel», imię to miał jeszcze Jozue, syn Nuna, zanim Bóg zmienił mu imię"21.

Podając taką interpretację Książę Egzegetów sięga do języka hebrajskiego i wyprowadza to imię od rdzenia hebrajskiego ישיע - ,pomóc”, „ratować”, ,przyjść na pomoc"22, czyli w przekonaniu Hieronima Ozeasz jest figurą Zbawiciela.

Wedle relacji biblijnej Gomer jest prostytutką, gdyż w Oz 1, 2 czytamy:

Wulgata: „Et dixit Dominus ad Osee: «Vade, sume tibi uxorem fornicationum»»" (liczba mnoga).

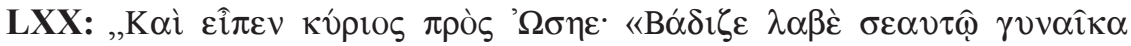

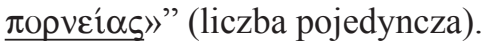

Komentując ten werset Książę Egzegetów sięga do hebraica veritas i podaje,

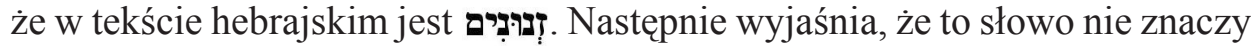
„nierządnica” czy też ,nierząd” lecz wskazuje na liczne nierządy, czyli Gomer w opinii Hieronima jest kobieta, która cudzołoży nagminnie, jako że odnotowuje w komentarzu do Oz 1, 2:

„Hebrajskie słowo ZANUNIM (זפונים) nie [znaczy] «nierządnica» czy też «nierząd», jak większość sądzi, lecz wskazuje na «liczne nierządy». Z tego wynika, że owa kobieta, którą prorok pojął za żonę, nie raz, lecz częściej dopuszczała się nierządów, a im bardziej ta stawała się brudniejsza, tym bardziej prorok był cierpliwy, który pojął taką za żonę"23.

Teraz podejmiemy próbę odpowiedzi na pytanie, jak Hieronim radzi sobie z tym przekazem biblijnym, gdyż nie dość, że Gomer jest małżonką (a jak już wcześniej zostało powiedziane autor Wulgaty niezbyt przychylnie odnosił się do tego stanu), to jeszcze jest prostytutką!

$\mathrm{Na}$ początku trzeba zaznaczyć, że Hieronim interpretuje Oz 1-3 w kluczu ponaddosłownym, a dokładnie, dopatruje się w tych passusach metafory małżeńskiej. Prorok Ozeasz w opinii Hieronima jest zawsze symbolem Boga, a ściślej Boga Ojca lub Chrystusa. Z kolei Gomer ma co najmniej potrójną symbolikę, gdyż w przekonaniu komentatora może być ona figurą Izraela, Kościoła albo heretyków.

a) Gomer - obraz Izraela. Analizując Oz 1, 2 autor Wulgaty dopatruje się w Gomer obrazu Izraela i poucza, iż Ozeasz, który wziął za żonę prostytutkę,

${ }^{21}$ Hieronymus, Commentaria in Osee 1, 1, PL 25, 819D: „«Osee» enim, in lingua nostra, «salvatorem» sonat: quod nomen habuit etiam Josue filius Nun, antequam ei a Deo vocabulum mutaretur", tłum. własne.

${ }^{22}$ Por. Koehler - Baumgartner - Stamm, Wielki słownik hebrajsko-polski, t. 1, s. 423, nr 3991.

${ }^{23}$ Hieronymus, Commentaria in Osee 1, 2, PL 25, 822B: ,Verbum Hebraicum ZANUNIM (זנונים), non «fornicariam» et «fornicationem», ut plerique aestimant, sed «multas fornicationes» sonat. Ex quo ostenditur mulier ista, quam propheta sumit in coniugem, non semel, sed frequentius fornicatam, ut quanto illa sordidior est, tanto sit propheta patientior, qui talem uxorem duxerit", thum. własne. 
nie uczynił tego z własnej woli, lecz był posłuszny rozkazowi Boga. Następnie wyjaśnia, że prorok przyjmujący Gomer jest symbolem Boga, który przyjął Synagogę, czyli naród żydowski, oddający się nierządowi, tak jak żona Ozeasza. Komentator chwali proroka za jego postawę i twierdzi, że prorok łącząc się z nierządnicą nie stracił swej obyczajności, tylko ona otrzymała obyczajność, której wcześniej nie posiadała. W opinii Hieronima człowiek, który trwa w dobrym, nie splami się, jeśli połączy się ze złym. Lecz ten, który jest zły, zwróci się ku dobremu, jeśli będzie postępował za przykładami człowieka dobrego:

„Prorok nie powinien być ganiony, [...] jeśli ulicznicę zwrócił ku obyczajności, lecz raczej chwalony, gdyż ze zła uczynił dobro. Bowiem nie ten, który pozostaje dobry, splami się, jeśli połączy się ze złym; lecz ten, który jest zły, zmieni się $\mathrm{w}$ dobrego, jeśli postapi za przykładami dobrego. $\mathrm{Z}$ tego wnioskujemy, że nie prorok stracił obyczajność łącząc się z nierządnicą, lecz nierządnica otrzymała obyczajność, której wcześniej nie posiadała: zwłaszcza że błogosławiony Ozeasz nie uczynił [tego] z powodu wyuzdania, ani żądzy czy też z własnej woli, lecz był posłuszny rozkazowi Boga, gdyż to co w nim odczytujemy cieleśnie, uznajemy, że w Bogu zostało dokonane duchowo. Ten przyjął Synagogę, to znaczy, naród żydowski, oddany nierządowi i żądzy"24.

Książę Egzegetów komentując Oz 2, 5: „Sequar amatores meos”, w owych kochankach dostrzega bóstwa narodów ościennych, a dokładnie Asyryjczyków, Chaldejczyków i Egipcjann ${ }^{25}$, z którymi według sądu komentatora, Izrael cudzołożył zwracając się do nich o pomoc w czasie wojen i rozmaitych ucisków. Tak jak Gomer porzuciła męża swego, „biegnąc do swych kochanków”, tak Żydzi odrzucili Chrystusa, świadcząc na rzecz Barabasza:

„«Pobiegnę za mymi kochankami»; [czyli] podążę do bóstw, które mi dostarczyły koniecznych [rzeczy] do pożywienia i do ubrania. Wszystko, co mowa prorocka opisuje, to Żydzi w interpretacji duchowej otrzymali od Pana. I ponieważ zaprzeczyli, że [Chrystus] jest Synem Boga, wybrali Barabasza, sprawcę rozbojów i rozruchów, a ukrzyżowali Syna Bożego (por. J 18)’”26.

${ }^{24}$ Tamże 1, 2, PL 25, 823A-B: „Nec culpandus propheta, [...], si meretricem converterit ad pudicitiam, sed potius laudandus quod ex mala bonam fecerit. Non enim qui bonus permanet, ipse polluitur, si societur malo; sed qui malus est, in bonum vertitur, si boni exempla sectetur. Ex quo intelligimus non prophetam perdidisse pudicitiam fornicariae copulatum; sed fornicariam assumpsisse pudicitiam quam antea non habebat: praesertim cum beatus Osee, non ob causam luxuriae, non libidinis, non propria fecerit voluntate, sed Dei paruerit imperio, ut quod in isto carnaliter legimus, in Deo factum spiritualiter probaremus. Qui suscepit Synagogam, hoc est, populum Iudaeorum fornicationi et libidini servientem", tłum. własne.

${ }^{25}$ Por. tamże 2, 6-7, PL 25, 832B-C: „Amatores autem Ierusalem et gentis Iudaeae, secundum historiam illius temporis, Assyrios atque Chaldaeos et Aegyptios nationesque caeteras intelligamus, cum quorum idolis fornicata est, a quibus bellorum tempore, et prementibus malis frustra speravit auxilium".

${ }^{26}$ Tamże 2, 4-5, PL 25 831C-D: „«Sequar amatores meos»; vadam ad idola quae mihi et ad 
Innym fragmentem, który komentator interpretuje alegorycznie w odniesieniu do Gomer jako obrazu Izraela jest werset z Oz 3, 1: „Et dixit Dominus ad me: «Adhuc vade, dilige mulierem dilectam amico et adulteram», sicut diligit Dominus filios Israel, et ipsi respectant ad deos alienos, et diligunt vinacia uvarum". Książę Egzegetów poddając swemu autorytetowi ów passus sięga do hebraica veritas i poucza, że w tekście hebrajskim w tym miejscu pojawia się rzeczownik, który składa się ze spółgłosek RESZ ( ) i AIN (У). Następnie Hieronim wyjaśnia, że słowo to można odczytać na dwa sposoby, a mianowicie jako „zło"27 albo „przyjaciel”"28. W opinii komentatora sposób odczytania tego wyrazu zmienia diametralnie sens omawianego wersu:

„Kiedy jest mówione, «ponownie», wskazuje, że wcześniej pokochał nierządnicę, która albo kocha zło, albo jest kochana przez przyjaciela i [mężczyznę jej] bardzo bliskiego: bowiem hebrajskie słowo RE (רע) trzeba odczytać jako «zło» albo «przyjaciel»"29.

Następnie zaznacza, że ponieważ Ozeasz pokochał kobietę, która jest grzesznica, zatem on musi być figurą Boga, który umiłował Izraela, czyli metafora miłości Ozeasza do Gomer jest obrazem więzi łączącej Jahwe z narodem wybranym, który choć doświadcza miłości Boga, to jednak zwraca się do obcych bóstw:

„Otóż, ponieważ prorok miłuje cudzołożnicę, a jednak nie współżyje z nią w małżeństwie ani nie łączy się [z nia] w nierządzie, lecz miłuje tak wielce grzesząca, jest typem Boga, który miłuje bardzo złych synów Izraela, którzy choć są miłowani przez Pana, to jednak zwracają się do obcych bogów i bóstw, i miłują pestki winogron, które nie zawierają wina, i utracili dawną chwałę"30.

Omawiana metafora małżeńska ma charakter dynamiczny i jest modelowana przez samego Boga, który kształtował miłość Ozeasza do Gomer na wzór swej miłości do narodu wybranego. Izrael jest miłowany przez Boga miłością bezgraniczną i bezwarunkową:

victum et ad vestitum necessaria praebuerunt. Omnia quae propheticus sermo describit, spiritualiter a Domino accepere Iudaei. Et quia Dei filium negaverunt, eligentes sibi Barabbam latrocinii et seditionis auctorem, et crucifigentes Filium Dei (Ioan. XVIII)", thum. własne.

${ }^{27}$ Hebr. ער.. Por. Koehler - Baumgartner - Stamm, Wielki słownik hebrajsko-polski, t. 2, s. 289$291, \mathrm{nr} 8654$.

${ }^{28}$ Hebr. רַע. Por. tamże, t. 2, s. 291-293, nr 8656.

${ }^{29}$ Hieronymus, Commentaria in Osee 3, 1, PL 25, 842A: „Quando dicitur, «adhuc», ostendit quia prius amaverit fornicariam: quae adultera, vel diligat illa mala, vel diligatur ab amico et proximo: RE (רע) enim verbum Hebraicum, vel «malum» legitur, vel «amicus»”, thum. własne.

${ }^{30}$ Tamże 3, 1, PL 25, 842B: „Ergo quia propheta diligit adulteram, et tamen non ei matrimonio copulatur, nec fornicatione coniungitur, sed tantum diligit delinquentem, typus Dei est, qui filios Israel pessimos diligit, qui cum diligantur a Domino, ad deos alienos idolaque respiciunt, et diligunt vinacia uvarum, quae vina non habent, et pristinam gratiam perdiderunt", tłum. własne. 
„I należy zaznaczyć, że ta cudzołożnica symbolizuje obecne położenie Żydów, którzy bez Boga i znajomości Pism i łaski Ducha Świętego są miłowani przez Pana, który pragnie zbawienia wszystkich i otwiera drzwi żałującym [za grzechy]"31.

b) Gomer - obraz Kościoła. O ile metafora miłości małżeńskiej, ukazująca związek Boga ze swoim ludem w relacji odrzuconej i zdradzonej przez oblubienicę miłości, wydaje się zrozumiała, to już interpretacja tej metafory jako relacji Boga do Kościoła jest co najmniej kuriozalna. W omawianym komentarzu do Ozeasza prostytutka Gomer jest także - w opinii Hieronima - obrazem Kościoła, a dokładnie symbolem miłości Zbawiciela do Kościoła. Tak jak Ozeasz wziął za żonę cudzołożnicę, tak też Chrystus założył Kościół na fundamencie Żydów i pogan:

„O Zbawicielu i figurze Kościoła powiedzieliśmy na wstępie, że wziął sobie za żonę nierządnicę, która wcześniej służyła bożkom"32.

Hieronim broniąc Ozeasza, który poślubił prostytutkę, szafuje argumentami na tyle, iż powołuje się na przykłady zaczerpnięte od Greków i usprawiedliwia małżeństwo z Gomer:

„Jeśli ktoś zaś [jest] uparty, a szczególnie spośród heretyków, nie chciał przyjąć tego, co zostało przenośnie powiedziane i wyszydził proroka łączącego się z nierządnica, stawiamy jemu przed oczy to, co Grecja ma w zwyczaju chwalić, a szkoły filozofów są [co do tego] jednomyślne"33.

Jednym z takich przykładów jest Polemon z Aten, który w młodości wiódł rozpustny tryb życia. Pewnego dnia, będąc pijany i z wieńcem na głowie, słuchał wykładu filozofa Ksenokratesa z Chalcedonu o umiarkowaniu, który wywarł na nim ogromne wrażenie. Od tego czasu diametralnie zmienił swój tryb życia. Stał się stanowczy i stałego charakteru, co w konsekwencji przyniosło mu sławę:

„Z tej racji sławią Ksenokratesa, męża niezwykle uczonego, który sprawił, że Polemon najbardziej rozpustny młodzieniec, [siedząc] pijany z bluszczem na głowie pośród kitarzystek i fletnistek oraz kobiet bezwstydnych, stał się posłuszny mądrości i zmienił się z młodzieńca bardzo nikczemnego w najmądrzejszego z filozofów"34.

${ }^{31}$ Tamże, PL 25, 842C: „Et notandum quia haec adultera praesens tempus significet Iudaeorum, qui absque Deo et notitia Scripturarum et gratia Spiritus sancti diligantur a Domino, qui omnium expectat salutem, et aperit ianuam poenitentibus", thum. własne.

${ }^{32}$ Tamże 1, 2, PL 25, 823C: „De Salvatoris et Ecclesiae typo in praefatiuncula diximus, quod sumpserit sibi uxorem fornicariam, quae prius idolis serviebat", tłum. własne.

${ }^{33}$ Tamże: „Si quis autem contentiosus, et maxime gentilium, noluerit figuraliter dictum recipere, et irriserit prophetam fornicariae copulatum, opponamus ei illud, quod solet laudare Graecia, et philosophorum scholae concinunt", thum. własne.

${ }^{34}$ Tamże: „Qua ratione praedicent virum eruditissimum Xenocratem, qui Polemonem luxurio- 
Innym przykładem, który podaje Hieronim jest filozof Fedon z Elidy, który po upadku swego miasta rodzinnego dostał się do niewoli i był zmuszony pełnić obowiązki odźwiernego w domu nierządu. Następnie został wykupiony z niewoli:

„Dlaczego Sokratesa wynoszą pod niebiosa, który Fedona, od imienia którego jest księga Platona, przeniósł do Akademii z domu publicznego z powodu okrucieństwa i skąpstwa [jego] właściciela, służącego żądzy wielu?"35

c) Gomer - obraz heretyków. W przekonaniu autora Wulgaty nierządnica Gomer może być także obrazem heretyków, ponieważ komentując $\mathrm{Oz}$ 2, 7: „Et sequetur amatores suos”, wyjaśnia, że według duchowej wykładni heretycy opuścili Kościół, tak jak Gomer swego męża. Heretycy porzuceni przez tych, którym zaufali wracają do Kościoła, podobnie jak żona Ozeasza, zawiedziona postawą swych kochanków:

„Według wykładni duchowej heretycy podążają za tymi kochankami, przez których często porzuceni, powracają na łono matki Kościoła, [uginając się] pod ciężarem przewin"36.

Historia powołania proroka Ozeasza i jego małżeństwo z prostytutką Gomer doczekało się bardzo wielu interpretacji. Już Ojcowie Kościoła próbowali wyjaśnić tę kontrowersyjną kwestię. Św. Hieronim w swoim komentarzu do Księgi Ozeasza mierząc się z przekazem biblijnym: „Et dixit Dominus ad Osee: «Vade, sume tibi uxorem fornicationum»" $(\mathrm{Oz} 1,2)$ odczytuje małżeństwo Ozeasza z Gomer w kluczu symbolicznym. W przekonaniu autora Wulgaty żona proroka może być symbolem Izraela, Kościoła czy też heretyków. Komentator, choć niezbyt przychylnie odnosi się do stanu małżeńskiego, a w jego mniemaniu dziewictwo jest najdoskonalszym stanem życia kobiet chrześcijańskich, jednak w komentarzu do Ozeasza powołuje się na przykłady zaczerpnięte od Greków i usprawiedliwia małżeństwo proroka z nierządnicą. A zatem kolejny raz objawia się Hieronimowa umiejętność szafowania argumentami na tyle, by wykazać, że każde polecenie Boga jest sensowne, nawet jeśli z punktu widzenia ludzkiego wydaje się absurdalne.

sissimum juvenem inter psaltrias atque tibicines et impudicas mulieres ebrium et hedera coronatum fecit obedire sapientiae, et adolescentem turpissimum mutavit in sapientissimum philosophorum", tłum. własne.

${ }^{35}$ Tamże, PL 25, 823C-D: „Cur Socratem ad coelum levent, qui Phaedonem, ex cujus nomine Platonis liber est, de lupanari, ob crudelitatem et avaritiam domini, multorum libidini servientem, in Academiam transtulerit?", tłum. własne.

${ }^{36}$ Tamże 2, 6-7, PL 25, 832C: „Hos amatores juxta intelligentiam spiritualem sequuntur haeretici, a quibus saepe deserti, malorum pondere ad sinum matris Ecclesiae revertuntur", thum. własne. 


\title{
GOMER - THE ANTI-IDEAL OF WIFE \\ OR THE MODEL METAPHOR OF BRIDE'S RELATION \\ ON THE BASIS OF ST. JEROME'S COMMENT ON HO 1-3?
}

\section{(Summary)}

In this article we included St. Jerome's standpoint on Gomer - the prostitute and wife of Hosea. This topic was presented in two stages. First, we analysed an issue of ideal woman according to St. Jerome. Then we presented a picture of Gomer in St. Jerome's comment on the Book of Hosea 1-3. The main point of this article was an attempt to answer a question how St. Jerome deals with conveying the biblical meaning, according to which the prophet on God's command marries an adulterous woman. This issue is very interesting, because the author of Vulgate had rather unfavourable attitude towards the institution of marriage and Gomer was not only married, but also a prostitute.

Key words: St. Jerome, A Commentary on the Book of Hosea, Gomer.

Slowa kluczowe: Św. Hieronim, Komentarz do Ozeasza, Gomer.

\section{BIBLIOGRAFIA}

\author{
Źródła
}

Hieronymus, Commentaria in Osee 1-3, PL 25, 819-845.

Hieronymus, Epistulae, PL 22, 325-1224.

\section{Opracowania}

Andersen F.-I. - Freedman D.-N., Hosea: A New Translation with Introduction and Commentary, New York 1980.

Kelle B., Hosea 1-3 in Twentieth-Century Scholarship, „Currents in Biblical Research” 7 (2009) 179-216.

Kelly J.N.D., Hieronim. Życie, Pisma, Spory, tłum. R. Wiśniewski, Warszawa 2003.

Koehler L. - Baumgartner W. - Stamm J.J., Wielki stownik hebrajsko-polski i aramejskopolski Starego Testamentu, red. wyd. pol. P. Dec, t. 1-2, Warszawa 2008.

Lexicon Hebraicum et Chaldaicum in Libros Veteris Testamenti ordine etymologico compositum, E.-F. Leopold, Lipsiae 1850.

RADLIŃSKI T., Św. Hieronim a kobiety, Lublin 2013.

SweEney M.-A., The Twelve Prophets, vol. 1: Hosea, Joel, Amos, Obadiah, Jonah, Collegeville 2000.

WolfF H.-W., A Commentary on the Book of the Prophet Hosea, Minneapolis 1974. 